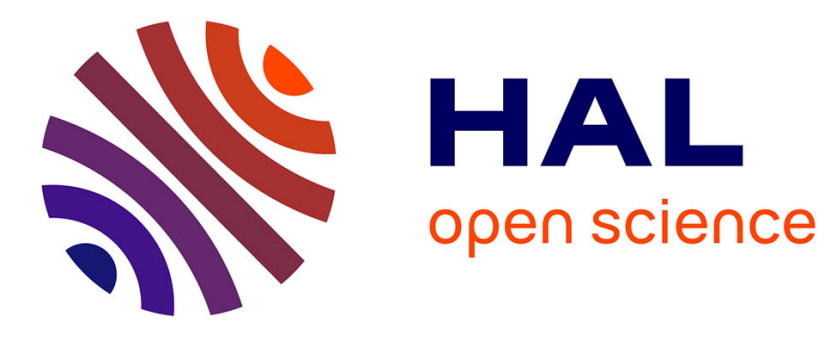

\title{
Scientific labour markets, networks and regional innovation systems
}

Helen Lawton Smith, Rupert Waters

\section{To cite this version:}

Helen Lawton Smith, Rupert Waters. Scientific labour markets, networks and regional innovation systems. Regional Studies, 2011, pp.1. 10.1080/00343404.2011.557655 . hal-00694721

HAL Id: hal-00694721

https://hal.science/hal-00694721

Submitted on 6 May 2012

HAL is a multi-disciplinary open access archive for the deposit and dissemination of scientific research documents, whether they are published or not. The documents may come from teaching and research institutions in France or abroad, or from public or private research centers.
L'archive ouverte pluridisciplinaire HAL, est destinée au dépôt et à la diffusion de documents scientifiques de niveau recherche, publiés ou non, émanant des établissements d'enseignement et de recherche français ou étrangers, des laboratoires publics ou privés. 


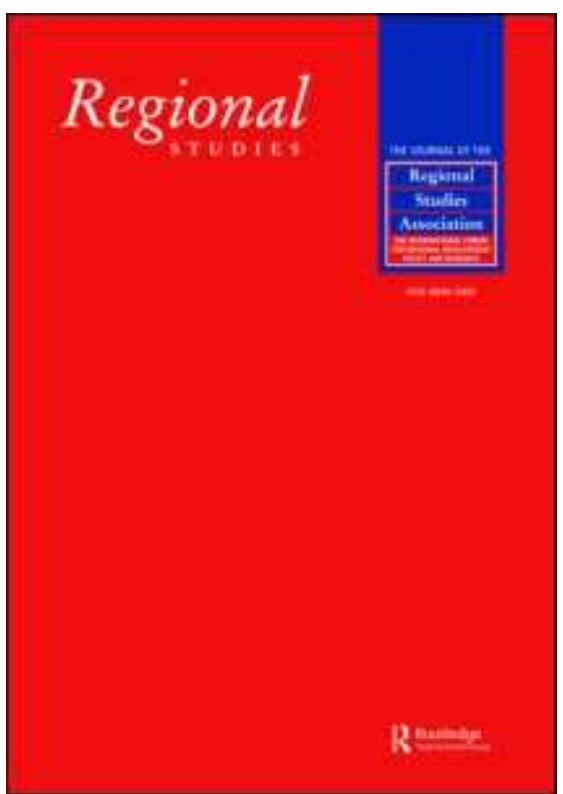

Scientific labour markets, networks and regional innovation systems

\begin{tabular}{|r|l|}
\hline Journal: & Regional Studies \\
\hline Manuscript ID: & CRES-2007-0282.R1 \\
\hline Manuscript Type: & Main Section \\
\hline JEL codes: & $\begin{array}{l}\text { O18 - Regional, Urban, and Rural Analyses < O1 - Economic } \\
\text { Development < O - Economic Development, Technological Change, } \\
\text { Incentives < O3 - Technological Change|Research and Development } \\
<\text { O - Economic Development, Technological Change, and Growth }\end{array}$ \\
\hline Keywords: & $\begin{array}{l}\text { scientific labour markets, regional innovatioin systems, Oxfordshire, } \\
\text { Cambridgeshire }\end{array}$ \\
\hline
\end{tabular}

\section{SCHOLARONE" Manuscripts}


SCIENTIFIC LABOUR MARKETS, NETWORKS AND REGIONAL INNOVATION SYSTEMS

Helen LAWTON SMITH* and Rupert WATERS+

* School of Management \& Organizational Psychology, Birkbeck, Malet Street, London WC1E 7HX

h.lawton-smith@bbk.ac.uk

+ University of Buckingham, Buckingham MK18 1EG, UK

rupert.waters@buckingham.ac.uk

\begin{abstract}
While quality of the labour force in a locality is the single most important component of local competitiveness (SIMMIE et al 2002), the RIS literature has relatively neglected processes of labour force development. This paper addresses two questions (i) what is the role of labour markets in the making of regions as innovative systems and (ii) what is the role of labour markets in Regional Innovation Systems. The labour market and specifically the networks that exist between highly skilled workers are positioned at the centre of the analysis, using evidence from the UK high technology economies of Cambridgeshire and Oxfordshire.
\end{abstract}

Keywords: scientific labour markets, regional innovation systems, Oxfordshire and Cambridgeshire

JEL Code 031 


\section{INTRODUCTION}

While quality of the labour force in a locality is the single most important component of local competitiveness (SIMMIE et al 2002), the systems of innovation literature, including the regional innovation systems (RIS) literature, has devoted relatively little attention to processes of labour force development (see for example the neglect of labour by COOKE 1998, CASPAR and VAN WAARDEN (eds) 2005, ASHEIM et al (eds) 2003). Yet a long line of studies dating back to KEEBLE 1989, ANGEL 1991, through to SIMMIE et al 2002, BERCOVITZ and FELDMAN 2006 and SAXENIAN 2006) have focused both on cumulative, hence systemic processes, whereby the highly skilled are attracted to particular locations by the presence of other professionals whose movement between employers is a crucial factor in transferring technology within regions or localities. The argument is that the absorptive capacity (COHEN and LEVINTHAL 1990) of the highly skilled is crucial in drawing in, assimilating and translating new knowledge and applying it commercially, with the 'embodiment' of knowledge in the regional labour force being one of the primary mechanisms through which such localization occurs (HOLMEN and DOLEREUX 2003, 15-16).

As such concentrations of expertise develop greater demands for coordination within labour markets arise. Studies have shown that at the early stages of new concentrations self-organising processes emerge whereby informal institutions develop that help reinforce the impact of labour as a key component of the innovation process (see GARNSEY 1998). Later there is a demand for more formal initiatives designed to coordinate the supply and demand of skills, for example to ensure that there is a matching process between the career needs of individuals and the skill needs of firms. Under some conditions the former include the development of communities 
of practice (BROWN and DUGUID 2000a) and 'learning communities' (BENNER 2003), while the latter might be skill specific training programmes. Therefore, if somewhere has a localised expert labour market system it is likely that there will be evidence of institutions, social as well as economic, which collectively comprise a system of governance within the localised component of a more geographically extensive highly-skilled local labour market.

Such fundamental issues of skill accumulation and the labour market mobility which lead to innovation through the transfer of knowledge are relatively neglected in the RIS literature. Taking coordination within localised labour markets as it theme this paper argues labour markets deliver innovation in particular places, driving regional innovation systems to a far greater extent than institutional arrangements - which rather than being instrumental in setting the climate for innovation, are reinforcing effects (see GARNSEY 1998).

The paper addresses two questions (i) what is the role of labour markets in the making of regions as innovative systems and (ii) what is the role of labour markets in regional innovation systems. In particular, in relation to both questions, we are interested in how flows of people (and knowledge) through (local) space are coordinated. Processes of coordination, we argue, are fundamental to understanding how regional labour markets contribute to knowledge transfer and learning. In this paper, we position the labour market and specifically the networks that exist between highly skilled workers at the centre of the analysis. We examine flows of people and knowledge through geographical space within local labour market for the highly skilled, using evidence from the high technology local economies of Cambridgeshire and Oxfordshire in the UK. 
The remainder of the paper is in three sections. In the first, the justification for the prioritisation of the role labour markers in RIS is reviewed. The second introduces evidence from a study of labour market mobility in the high-technology local economies of Oxfordshire and Cambridgeshire. The third draws some conclusions. We argue that localised RIS in Oxfordshire and Cambridgeshire can be observed in patterns of intra and inter-regional mobility but that evidence of the localisation of national and global innovation systems is stronger.

\section{CONCEPTUAL FRAMEWORK}

Recent literature has focused on the interdependence of intra and inter-firm learning processes in firms (MAKINEN 2002), in collective learning at the local/regional scale (LUNDVALL 1988, STORPER 1995, LAWSON 1997) and in the institutions which emerge to sustain both (GARNSEY 1998, BENNER 2003, ISAKSEN 2005). It is only recently that how labour markets contribute to both and hence to regional innovation systems has become the focus of attention. In part one of the literature review we consider the key concepts of regional innovation systems in order to identify where labour might fit into definitions of RIS, which we discuss in part two.

\section{(i) Regional Innovation Systems}

Regional innovation systems are extremely varied in form and as systems in process (see COOKE 1998). HOWELLS (1999) for example, points to three dimensions of RIS: regional structure - administrative, legal, constitutional and institutional arrangements; the long-term evolution and development of regional industry specialisation, and the additional core/periphery differences in industrial structure and innovative performance. The last relates to higher order versus lower order functions and activities and patterns of government expenditure. He also argues that RIS are 
crucial arenas for localised learning and tacit know-how sharing - the informal links between key personnel. In spite of this variety, definitions of RIS have at least three points in common: they all stress boundaries, governance, and industrial specialization/clustering and associated interactive learning processes. We next discuss these points drawing on studies which have emphasized different aspects of each, to develop understanding of the RIS concept, in general and then specifically in relation to labour markets.

One of the most difficult issues in identifying the existence of an RIS as opposed to an administratively defined area, is that of whether the system can be seen to have distinct features. For EDQUIST (2004) (in ROPER et al 2006), like HOWELLS, boundaries, functions and co-ordination are the identifiers of the existence of an RIS. EDQUIST suggests that there are three criteria that must be met if an innovation system is said to exist in an area: coherence - demonstrated by feedback loops, common developmental trajectories and complementary competencies between agenda; unified function where there are identifiable objectives or aims to which all elements of the system contribute; and being bounded - creating the possibility of discriminating between the system and the rest of the world.

ASHEIM and GERTLER (2005) address the issue of coherence from a rather different perspective on clustering and interactive learning, to the standard discussions of types of cluster specialisation (see for example the discussion in Martin and Sunley 2003.) In their categorisation of industries and their industrial contexts they distinguish those with an analytical knowledge base (most closely akin to high-tech sectors) or those with a synthetic knowledge base, the key features are presented in Table 1 below. The former are those industries that rely on scientific knowledge such 
as IT and biotech, where the production process draws on sources of knowledge, and tend to draw upon research results from universities or national laboratories. Universities, whose contributions to the labour market are underplayed in regional innovation literature, therefore, might be expected to play an initial role in diffusing technological knowledge through graduate recruitment. In the latter the innovation process involves the application of existing sources of knowledge or new combinations of knowledge. This often occurs in response to the need to find technical responses to specific problems that emerge from interactions between clients and suppliers. In these conditions, labour market processes might be more interesting in the synthetic model as there is less reliance on codified knowledge, which is more important in the analytic model where universities might be expected to play a more downstream role (ASHEIM and COENEN, 2006).

The distinction between analytic and synthetic clearly relates to boundaries, governance and industrial clustering and specialisation and the associated aspects interactive learning as it includes the recognition of the different research and institutional structures required to support the knowledge base in the cluster (WOLFE et al 2005). Thus in regional innovation systems based on analytical knowledge (hightech economies) there will be different processes of coordination between the various actors compared to those based on synthetic knowledge, in which the operation of labour markets will in turn differ in their significance. 
Table 1 here

Governance is a key element in the RIS concept as it is that which defines how a system is formally organized to overcome market (MALERBA 2002) and or system failures (WOOLHUIS et al 2005). It is expressed as both government and nongovernmental activities (STOKER 2000). With respect to scientific labour markets, formal policy structures include private sector organisations such as branches of industry associations and chambers of commerce which have responsibilities for addressing skills issues, and public organisations such as universities and polytechnics, regional ministries and skills councils with devolved powers concerning enterprise and innovation support, particularly for small and medium-sized enterprises (SMEs).

Universities' contribution to local labour markets, which might be expected to be pivotal in sustaining localised innovation systems, is problematic if the evidence from an OECD is accepted. This finds that although there is a positive correlation between secondary and tertiary educational attainment and economic performance, it is much stronger for secondary education, while 'university education makes a relatively modest contribution' (OECD 2001, 96). HOMMEN and DOLEREUX (2003, 18) comment, 'These results hardly bear out the expectation that 'elite' labour and higher education are vital for 'learning regions'. Further reference is therefore made to case study evidence on the importance of 'industry structure, the curriculum of [a region's] universities, and the degree of co-ordination between education and industry'. Moreover, while universities teach codified knowledge to students, there is no guarantee of a match between teaching and the kinds of students required by the firms 
in the hinterland of the university - they are not necessarily mutually reinforcing. Hence there is potentially a difference between universities with a regional mission (such as Newcastle University) and those without (such as Oxford University) and the types of universities needed in core and peripheral areas (BENNEWORTH, 2005). In addition, there is no a priori assumption that the highly skilled will absorb the kinds of knowledge that have practical applications in the regional economy. Therefore universities do not easily sit into universal assumptions about the elements of a wellfunctioning RIS because of their lack of consistency in impact in any or all of boundaries, governance and industrial specialisation/clustering.

(ii) Labour markets processes in RIS

Labour markets have tended to be omitted from discussion about RIS in economic geography. Yet labour markets are central to understanding how systems develop. Knowledge transfers cannot occur without stocks and flows of highly skilled people and their networks (see SCOTT 2006, earlier identified by SIMMIE et al, 2002) in explanations of clustering behaviour and economic development (BERRY and GLAESER 2005) and informal and formal governance structures. Attention on the highly-skilled is long overdue, especially as the general trend in Europe and the US is for an increase in the number of jobs requiring science and engineering (S\&E) skills. As with RIS, interdependent effects are at work. Here we identify four dimensions which relate to the general literature on RIS: stocks, flows, networks and informal and formal governance systems.

The first of these are stocks of creative and educated people in a region. It is they who have the capacity to absorb and process knowledge (DANKBAAR, 2004). Firms gain from an increase in the overall stock of the highly skilled, both in the size and quality of the workforce. Regional or local growth depends on developing special types of 
incentive strategies that build on the ways in which tertiary education and other institutions influence innovation through human capital formation and development. These are the recruitment of graduates and post-grad students, and increasingly important foreign students; placement schemes; continuing professional development and extension programmes; vocational courses and public access to lectures and libraries, museums, galleries and sporting facilities. Both technical and business skills are required for firm competitiveness. While universities and other colleges are sources of skills, national laboratories also have an educational role, training both the highly skilled in science and engineering disciplines and technical experts such as technicians and laboratory assistants. SCOTT (2006) while recognising FLORIDA's (2002) argument that creative people are a key element of the contemporary creative city, argues that the production system is at the heart of understanding the system of employment which will attract, employ and train such people over any reasonably long run period. This complements HOWELL'S (1999) point about regional industrial specialisation as a feature of innovation systems.

Second, flows refer to both mobility of personnel within as well as into and out of a region. Both have implications for firms' organisational strategies and individual's career development (GREEN and CANNY 2003) as well as the human capital resources in particular cities and regions (CHAMPION and COOMBES 2005). Intra region mobility is both a competitive process and form of coordination of knowledge flows, both contributing to the creation of an RIS. MASSEY (1995) for example, argues that a better understanding of processes can be obtained by examining collective activity within high-technology labour markets. She describes how in such highly differentiated labour markets, a dynamic of competition is created in which it is necessary for both employers and employees to have a detailed knowledge of the 
market. Like ANGEL (1991) MASSEY finds that scientific workers change jobs frequently. She also finds that they belong to a professional community which extends beyond and cuts across the confines of the firms that employ them. The professional labour market does not operate in terms of simple supply and demand, nor does it operate in terms of cost. MASSEY $(1995,138)$ argues it is a 'very individualistic labour market' in which particular people are sought, singled out by their possession of knowledge, a monopoly, she argues, they have developed through the separation of conception from execution. She notes that scientists are highly mobile, and that to a large extent they choose their employers, so that work follows them and not vice versa. MASSEY argues that the clustering effect caused by the locational preferences, for example of electronic engineers (citing KEEBLE 1976) is reinforced by the way in which the labour market for their skills operates. The labour market is able to operate in this fashion due to the nature of the electronics product market; firms compete through quality, innovation and new products at least as much as through cost so that 'what is being bought on the labour market is not just labour power but scientific knowledge'.

Scientific knowledge is also transferred through recruitment by industry of graduates and employees from universities and other research institutions. In this respect, the scientific labour market can be seen as a 'bridging institution' between academia and industry for the co-production and transfer of knowledge and competences (LANCIANO-MORANDAT and NOHARA 2002.) Yet as MICHIE and SHEEHAN (2003) find, high commitment organisations or transformed workplaces are positively correlated with innovation (in ASHEIM and COENEN 2006). Thus barriers to technology transfer (LAWTON SMITH 1998) may be overcome by labour mobility. KEEBLE et al $(1998,20)$ emphasise the importance of the movement of the highly 
skilled between local employers arguing that the 'local inter-firm movement of skilled staff plays an important role in the intra-regional transmission of expertise and fostering of inter-firm links'. While HENRY and PINCH (2000) suggests that the place is important, KEEBLE 1989 and SEGAL QUINCE (1985) show that it is through people that the place keeps ahead. With regard to the success of its high technology econony SEGAL QUINCE $(1985,33)$ noted that 'Cambridge is not only a good place in which to recruit, but of greater significance, also in which to recruit outstanding people'.

Flows of people into a region (and out of a region) are an important component on the making of a RIS, but as GREEN (2006) points out, is less well researched. This is particularly so with respect to international mobility within Europe, possibly because international mobility between European countries has not yet become a major pattern, the trend is still one of outflows to the US (MASON 2000). More important is mobility between regions. As FLORIDA (2002) argues, the key to economic growth lies not only in the ability to attract the creative class, but also to translate that underlying advantage into creative economic outcomes in the form of new ideas, new high-tech businesses and regional growth. Other evidence while not wholly supporting FLORIDA's thesis, has identified that the tendency of initially skilled places to become more skilled over time (BERRY and GLAESER 2005) as more individuals become entrepreneurial and others move into a region. Supporting SCOTT's argument, BERRY and GLAESER find that if skilled people are more likely to become entrepreneurs (who are relatively immobile) and innovate in ways that employ other skilled people, then this creates an agglomeration economy where skilled people want to be around each other. This has a reinforcing, circular causation effect identified long ago by MYRDAL (1957) and indeed by MARSHALL (1922) 
who emphasised the quality, mobility and flexibility of the labour market as being key to transferring ideas within industrial districts.

The attraction of various types of talent (students, researchers, IT specialists, research scientists etc.) is now a formal governance agenda. Measures include tax incentives, repatriation schemes and improving the attractiveness of academic careers (OECD 2004). BACHTLER (2004) proposes that attracting star academics, researchers and highly skilled knowledge workers is increasingly replacing inward investment as a key role for regional development agencies. He cites Quebec, where the government is offering five-year income tax holidays to attract foreign academics in IT, engineering, health science and finance to take employment in the region's universities. In Finland, Nokia invests in the cultural adaptation of foreign IT workers as a way to improve productivity but also to help to retain this 'talent' (OECD 2004). Therefore, mobility is central to understanding co-ordination within the innovation process. Due to the fact that key industry clusters tend to be territorially based, talent attraction initiatives may be best designed by city and regional bodies that have strong industrial connections and a good knowledge of the local labour market (BACHTLER 2004).

Thirdly, networks are a key co-ordinating mechanism of information flows (LAMBOOY 2004). LAMBOOY argues that networks fulfil two functions: the first is facilitating the co-ordination of decisions made by separate entities (or nodes) of the networks and the second is the transformation of data, information and knowledge by using or making connections. These take the form of 'communities of practice' and 'learning communities; in local and regional settings (e.g. BROWN and DUGUID 2000b; SCHOENBERGER 1999; BENNER 2004). 
Finally, formal governance systems sit along-side informal system of coordination through networks. Shortages of skills which arise when clusters become established create a demand for governance systems in the form of training and financial systems etc and so on. These present particular policy problems resulting from Myrdal-type polarisation effects whereby the rich get richer. Such policy implications are addressed by FLYNN (1988) in HOMMEN and DOLEREUX (2003). He emphasised the importance of adopting a life cycle framework in human resource planning arguing that institutional factors such as the mix and characteristics of firms and human resources, and the timing of adjustment to avoid shortages and surpluses of labour and of anticipating institutional conflicts and problems in education and training policy need to be taken into account. HOMMEN and DOLEREUX argue that such an approach is particularly needed as regional or local policy makers may underestimate the difficulties in developing cooperative governance structures. Such problems stem from macro-economic conditions and national state policies which influence regional or local labour markets.

The policy dilemma at the local level is that graduate recruitment and retention means both finding local jobs for people from the universities and recruiting new students from the local population into the region's universities. Particular problems lie in matching supply to the demand for skills. While some parts of an economy may have a high demand for graduates and technicians such as high-tech SMEs and research institutions, other firms, particularly low-tech small firms, are not able to meet the challenges presented by new technologies. In the UK for example, a general weakness of SMEs is insufficient training and graduate recruitment. Nationally, between 30 per cent and 40 per cent of firms employ no graduates (CURDS 2000). Thus there is a role of governance in co-ordinating appropriate responses to this problem by 
facilitating the provision of the better training of undergraduates, graduates, and other employees in industry - necessary if SMEs are to recruit graduates and make the best use of them. Such intervention could strengthen the links between further and higher education sectors and the local economy and ensure a strong value chain of skills. Central to these activities are (i) the identification of where Higher Education Institutes (HEIs) jointly can offer training and (ii) an intelligence gathering role about vacancies and availability of personnel which span the city-region and its hinterland.

In conclusion, the selection of the empirical material which follows is based on the key points made above. These are that RIS are constructed through labour market processes in which stocks of highly-skilled labour are accumulated and flows of knowledge are facilitated through career mobility, networks and interactive learning. These comprise informal systems of governance and which may create a demand for intervention by formal institutions. This paper now explores these aspects of RIS development, focusing particularly on stocks and flows of the highly-skilled, particularly with respect to career mobility and the means by which this is facilitated.

\section{THE CASE STUDIES: OXFORDSHIRE AND CAMBRIDGESHIRE}

The two counties, although not the largest concentrations of high-tech activity in the UK, are among the fastest growing centres and have dense populations of research activity and highly skilled people in high-tech SMEs and research institutions. They are both exemplars of foci of analytic knowledge-based systems and interactive RIS. Their importance in the UK's 'knowledge-economy' as a whole and in particular sectors such as bioscience has been recognised by central government (see for example SAINSBURY 1999; TRENDS BUSINESS RESEARCH for the DTI 2001 and the LAMBERT REVIEW 2003). 
The two counties are both located about 50 miles from London, Cambridgeshire to the North and Oxfordshire to the West. They are similar in size and population. Cambridgeshire covers 1300 square miles and has a population of 684,000; Oxfordshire's area is 1000 square miles with a population of 598,000. Both have historic and influential universities and the residential attractions of cultural centres. Scientific and technological resources are concentrated in their university and government laboratories, providing centres of knowledge capable of supporting hightech commercial activity.

Comparisons of levels of extent of entrepreneurship in high-tech economies depend on the definition of high-tech. For example CHADWICK ET AL (2003), using the Eurostat definition finds that Oxfordshire has 54,600 employees in 1,936 firms in 2002. However, using a more realistic and narrower Butchart-based approach using official statistics - for example excluding motor vehicle manufacture, but including Motorsport, 36,682 were employed in 1,400 firms, accounting for 12 per cent of employment in the county. Using their own broad definition but based on Eurostat, the estimate for Cambridgeshire for the end of 2001 was 48,300, about 13 per cent of employment in an estimated 1,526 'establishments'. The method of selecting firms on a case-by-case basis and non basic sectors such as wholesale and retail are discarded hence the Eurostat definition is not followed exactly (Personal communication Cambridgeshire County Council 2002). CHADWICK ET AL (2003) using the second approach demonstrate that a difference between the two counties was in the rate of growth. Oxfordshire had the highest percentage rate of growth in high-tech employees of all English counties in the period 1991-2000 (141 per cent) compared to Cambridgeshire which was eighth with an increase of 53 per cent. 
Each county therefore has high and growing concentrations of indigenous high-tech firms formed by local, often academic, entrepreneurs in diverse sectors. In particular both are leading growth centres for the UK's biotechnology industry. CHADWICK ET AL (2003) show that the number of firms and employment in key high-tech sectors in Oxfordshire in descending order is Software, Web/internet and other computer Services (635 firms employing 7,900), Other R\&D activities $(44,5,900)$, Instruments, Medical and Optical Equipment (112, 5,000), Biotech, Pharmaceuticals \& Medical Diagnostics, (73, 3,300) and Technical Consultancy and Testing (317, 3,300). Similarly the IT sector is the predominant sector in the Cambridge Cluster $(160,4,200)$, with Biotechnology $(153,5,300)$ and Electronic Equipment \& Instruments $(106$ 3,000) the second and third largest number of firms (LIBRARY HOUSE 2003). Hence both locations are dominated by computing/physics/engineering/chemical skills and illustrate BERRY and GLAESER's (2005) point about increasing agglomeration economies, whereby initially skilled places become more skilled over time (see also Table 2).

They differ in that there is a higher proportion of small firms in the Cambridge region and a higher proportion of larger firms in Oxfordshire; Cambridge is more serviceorientated while Oxford has a greater orientation to manufacturing and Cambridge has a concentration of technical consultancies while there are none in Oxford. Cambridge has retained the position it held in the 1970s and early 1980s as a leading centre for the personal computer and software sectors (KEEBLE and KELLY, 1986), although Oxfordshire is home to the largest UK manufacturer of educational computers (Research Machines). With regard to the research base, Oxfordshire has a greater density of public sector research laboratories, for example in atomic energy (UKAEA Culham) and scientific research (CCLRC, Council for Central laboratories of the 
Research Councils Rutherford Appleton Laboratory. Since 2007 the CCLRC has become the Science and Technology Facilities Council, STFC) while Cambridge has a higher number of multinational research laboratories than Oxford. In Cambridge they include Schlumberger, SmithKline Beecham, Toshiba, Sony and Microsoft, and in Oxford, Sharp, Dow Elanco and Esso (GARNSEY and LAWTON SMITH 1998). Given this mix of institutes and small firms, both counties can be classified as 'interactive RIS' (COOKE 1998) (i.e. degree of 'associationalism' higher than average, mixture of large and small firms and public and private R\&D)

Stocks of human capital

Both Oxfordshire and Cambridgeshire have high proportions of well-qualified residents compared to the rest of England \& Wales. Table 2 shows that 27 per cent of Oxfordshire residents and 25 per cent of Cambridgeshire residents are qualified to degree level (National Vocational Qualification (NVQ) level 4+) to rank as the $2^{\text {nd }}$ and $6^{\text {th }}$ most qualified counties respectively in England and Wales. These figures mask the range of performance recorded for the local authorities that make up the counties. Cambridge City is the strongest performer with 41 per cent of residents qualified to degree level to rank $8^{\text {th }}$ of the 376 local authorities of England and Wales while in Oxford City the proportion is 36.8 per cent to rank $12^{\text {th }}$.

Table 2 here

Outside the cities, South Cambridgeshire, which surrounds Cambridge City, also has a highly qualified workforce ranking $29^{\text {th }}$ in England and Wales with 29.8 per cent of 
residents holding degree level qualifications, East Cambridgeshire is the next strongest performer in the county with a national ranking of $136^{\text {th }}$. In Oxfordshire, the fall is not so sharp between districts, with all of the counties' local authorities scoring above the national figure. Oxford City and Cambridge City rank respectively $1^{\text {st }}$ and $2^{\text {nd }}$ in England and Wales for the proportion of residents qualified to NVQ level 3 with 19.0 per cent and 18.0 per cent respectively.

Although the proportions show the bias in favour of 'knowledge workers', it is important to put these proportions into perspective. The actual numbers are less impressive than the proportions but are a truer reflection of scale. Other counties such as Berkshire, Hampshire and the London region have more very highly skilled people.

Table 3 shows the occupational structure of the two counties based on Standard Occupational Classifications (SOC) ${ }^{1}$. The counties of Oxfordshire and Cambridgeshire rank $2^{\text {nd }}$ and $3^{\text {rd }}$ respectively of the 42 NUTS 2 regions in England and Wales behind Inner London, while the cities of Oxford and Cambridge rank respectively $3^{\text {rd }}$ and $2^{\text {nd }}$ of the 376 local authorities in England and Wales with 28.0 per cent and 23.4 per cent of residents respectively employed in professional occupations (SOC2) compared to the national average of 11.2 per cent. Table 3 does however highlight the relative shortage of associate professional and technical workers in both local economies.

Table 3 here

\footnotetext{
${ }^{1}$ For a full explanation see www.statistics.gov.uk/methods_quality/soc/structure.asp
} 
Rates of turnover exhibited in the UK labour market as a whole.

The pace of employment turnover in the UK overall is increasing. In their study of job tenure, GREGG and WADSWORTH (1999) found that the average job in Britain lasts for a little over 5 years. They additionally found that the average new job lasts for 15 months - that is to say that workers can be expected to continue to move between jobs before finding an appropriate job match. More recently, the Chartered Institute of Professional Development (CIPD) Labour Turnover Survey for 2000 (CIPD, 2001) recorded an average overall turnover rate for full time workers of 21 per cent (giving an average job tenure of 4.6 years). A comparison of average job tenures from recent studies is presented in Table 4 below.

Table 4 here

In IT and high-technology sectors CIPD data gives an average job tenure of 5.1 years. The CIPD data therefore shows job tenures in the UK's high technology and IT sector to be longer than for professionals as a whole. In Motorsport Valley, a sectorally specialised cluster which includes Oxfordshire, the level of turnover is the highest recorded suggesting that there are important sectoral variations (PINCH and HENRY 2000) and possibly that skills are more easily transferred between very similar firms than between co-located firms even though they might have similarly well qualified workforces. In this sense, the networks that develop provide a means of coordinating knowledge flows within labour markets. 


\section{METHODOLOGY}

Data was collected from three postal surveys of the highly skilled between November 2000 and August 2001. Questionnaires were sent to the members of the Institute of Electrical Engineers (IEE), the Institute of Physics (IOP) and the Royal Society of Chemists (RSC) in the two case study areas. These three institutes represent the scientists and engineers of the case study areas. As far as we were able to ascertain, a biological sciences institute does not exist and as much of the science behind biological sciences is chemistry-based, for example bio-chemistry, many working in that field belong to the RSC. A total of 6,099 questionnaires were sent out to institute members in Oxfordshire and Cambridgeshire yielding 831 usable responses. The returns by institute and case study are presented in Table 5 below.

Table 5 here

The response rate of 14 per cent is typical for this type of survey providing sufficiently large samples for both case study areas and institute membership to allow analysis by both place and branch of science and compares favourably with previous studies of high-technology local economies. For example, ANGEL's 1991 study of Silicon Valley was based on a postal survey of 67 firms (representing a 14 per cent response rate), SEGAL QUINCE WICKSTEED'S (2000) update to the Cambridge Phenomenon was based on a study of 12 firms, while HENRY \& PINCH (2000) based their study on the careers of 100 engineers employed in Motorsport Valley. 
THE HIGHLY SKILLED IN THE OXFORDSHIRE AND CAMBRIDGESHIRE REGIONAL INNOVATION SYSTEMS

The agglomeration of science and engineering employers in both Oxfordshire and Cambridgeshire and associated world class research bases could be expected to lock people into the local labour markets, where high quality jobs in a number of firms can allow movement between companies where skills are transferable, and facilitated by the local social networks associated with specialist and confined labour markets.

In their study of Motor Sport Valley in the UK - which includes Oxfordshire HENRY and PINCH $(2000,128)$ note that:

\begin{abstract}
"Motor Sport Valley acts as the epicentre of a global, yet highly spatially defined labour market ... As an individual in motor sport, it is rare that you do not at some point in your career, spend some time within Motor Sport Valley ... essentially this is about joining the knowledge community of motor sport production. Yet opportunities exist in this highly mobile industry to sell your knowledge elsewhere and many do so ... Thus few stray away from the Valley for long, returning once more to reconfigure their position within the community of knowledge".
\end{abstract}

In the case of the motor sport industry then, Motor Sport Valley is clearly the world's most important location, whereby workers who leave must return to work in the cluster if they are to keep fully abreast of technological developments and to ensure the currency of their networks. The Oxfordshire and Cambridgeshire innovation systems are not so tightly defined, operating across a number of high-technology industry sectors, nevertheless the comments selected from our survey presented in Box 1, demonstrate that Oxfordshire in particular is a technologically glamorous 
location. However in contrast to Motor Sport Valley, the optimum place of work is likely to be a particular organisation rather than the cluster itself.

The survey of the highly skilled mapped the career trajectories of respondents. In both case studies it was most common for those currently employed to have previously worked elsewhere and to have subsequently moved into the areas. This was true for all three institutes. Although no statistics exist for the population of the UK as a whole, this situation is not unexpected, but does have implications for organisational strategies, where decisions to expand or remain may be affected by the propensity of individuals to move into the locality and the career development of individuals (cf GREEN and CANNY 2003).

The findings presented in Table 6 below offer limited support for making the case that Oxfordshire and Cambridgeshire are important world centres of scientific expertise. The proportion of the sample which had moved in and out of the respective local economies was highest in each of the institutes in Cambridgeshire than in Oxfordshire reflecting the smaller firm size in Cambridgeshire, and the large internal labour markets therefore available in Oxfordshire, and the shorter average job tenure (LAWTON SMITH and WATERS, 2005). The table tells us who is there at the moment. 'One way' refers to moving into either Oxford or Cambridge, in and out means that they have taken a job outside the area and then returned. 'First job' means that this is their first career move. This provides some support for the BERRY and GLAESER (2005) argument about the reinforcing effects of entrepreneurship on cluster development.

Table 6 here 
Although there are no IEE respondents who have conducted all their careers in either Oxfordshire or Cambridgeshire sizeable minorities in both Oxfordshire and Cambridgeshire had begun careers in that location and not left - ranging from 14 per cent for Oxfordshire physicists to 20 per cent for the county's chemists. This is in addition to the numbers who are still in their first job - regardless of time in that position which was 37 years in the case of one Cambridgeshire chemist. The IEE is the least qualified profile of the three institutes and so may not be in such global demand as for the physicist and chemists. But for the most highly qualified, Oxford and Cambridge are the places to be.

Validation for these findings is provided by the analysis of the 2001 UK Census presented in Table 7 below. This shows that the cities of Oxford and Cambridge respectively have the least and second least settled populations of all English local authorities and the 6th and 4th highest proportion of the present population to have been living outside the UK a year previously (at 3.8 and 4.1 per cent respectively). Their respective labour markets for the highly skilled can therefore be seen to be located within counties used to exceptionally high levels of migration. Just under a fifth (17.4 per cent) of survey respondents had over the course of their careers previously worked abroad. The proportion varied by discipline ranging from 8 per cent of electrical engineers in Oxfordshire to 23 per cent for the same county's physicists.

Table 7 here

These findings are interesting when considered in conjunction with analysis of the results of where respondents would look for their next job. Where respondents would 
look overseas, their previous job histories suggest that these answers are not entirely aspirational, rather they reflect a realisation of their worth in the wider hightechnology labour market. However, the proportion of respondents who would look locally is notable given the previous geography of their employment, perhaps reflecting the need to consider family and the practicalities of repeated moves for homeowners may be reflected in the high proportion of respondents who would look locally, reflecting the quasi-immobility (CAMAGNI, 1991) of the highly skilled despite the global demand for their labour. The results of the analysis by location are presented in Chart 1 below.

Respondents from the IEE were the most likely to only look for their next position within their own county, and accordingly the least likely to consider continuing their career overseas - with the US as the most common overseas choice, but recording only eight per cent of the stated locations. The table shows a UK focused labour market.

Chart 1 here

The advantages of carrying out a career in the Oxfordshire and Cambridgeshire as recorded by the survey of the highly skilled are presented in Chart 2 below. The effect of family ties is demonstrated by the response 'it is home' being the most common response in Oxfordshire and the second most common in Cambridgeshire. However, 'career possibilities' and access to university research' were the other most popular responses, followed by 'ease of finding work', all of which suggest the presence of agglomeration economies within each regional innovation system (cf 
Chart 2 here

Chart 3 below presents the means by which the highly skilled in Oxfordshire and Cambridgeshire found their current job. Despite the clustering effects noted above, it is the printed advertisement that is overwhelmingly the most common way to have found employment, ahead of word of mouth in both case studies. Hence on this indicator, networks are not a major source of coordination within the labour markets, and that the interactive RIS model of associationalism is limited in this respect at least.

When the stage of career is considered different findings emerge. For those in their first job formal methods of job searching - printed advertisements and particularly direct applications to companies - are the most common forms, however the informal mechanisms we would expect to be visible in regional innovation systems are still prevalent, suggesting a strong link between the education institutes of Oxfordshire and Cambridgeshire and their local high technology local markets. With the exception of the Oxfordshire's electrical engineers respondents in their first jobs had made found their current positions by being contacted by their employers directly or through the use of employment agencies, highlighting the importance of the networks developed by individual scientists and engineers through work. 
Charts 3 and 4 here

\section{CONCLUSIONS}

In this paper we set out to address two questions (i) what is the role of labour markets in the making of regions as innovative systems and (ii) what is the role of labour markets in regional innovation systems. We argue that that the coordinating role of labour markets is key to understanding both. The framework for analysing regional innovation systems from this perspective identified three common elements, boundaries, and industrial specialization/clustering and interactive learning, and governance, while the review of the literature on the role of labour markets identified four interrelated elements: stocks and flows of labour, networks, and informal and formal governance systems. Evidence from the two case studies has been used to explore these themes.

Defining the boundaries of RIS, industrial specialisations and clustering using labour market data of stocks of skills as indicators is always inexact. Instead, it maybe enough to point to the centre of labour markets, recognising that distance decay effects and centripetal forces draw in skilled people to and from particular locations, effects which contribute to the operation of regional innovation systems. We focus on industrial structures, using the distinction made by ASHEIM and COENEN (2006) of analytic and synthetic knowledge, arguing that Oxfordshire and Cambridgeshire are exemplars of the former. Here we show that the stocks of the highly-skilled (scientifically qualified and professionals) in each county marks them out as distinctively different to other locations, particularly in the cities of Oxford and Cambridge and show evidence of specialised clustering and the reinforcing effects identified by BERRY and GLAESER (2005). Both locations appear to be focal points 
of UK-wide labour markets for chemists and physicists. It is also shown that the RIS what appear to be very similar locations have differing characteristics. This is because their hinterlands are different. Cambridge as more of a stand-alone city-type innovation system whereas in Oxfordshire there is more evidence of a more geographically unified scientific/professional labour market, with generally stronger patterns of in-mobility.

Here we are interested in how flows of people (and knowledge) through (local) space which give rise to interactive learning and networks are coordinated. Mobility as a means of facilitating knowledge transfer, within and between spatial scales we argue, is essential in understanding how regional labour markets contribute to knowledge transfer and learning. The evidence points to considerable mobility into each region, supporting the argument that the agglomeration of skills (BERRY and GLAESER 2005 ) is the key component of the making of regional innovation systems. We show how the two counties - places which started with higher levels of human capital than most of the rest of the UK have attracted more skilled people over the last two decades, created by local entrepreneurs (Box 1 and Table 6), thus creating RIS of particular kinds - analytic knowledge in both cases with strong accumulations of codified knowledge. This is supported by evidence in Chart 1 which shows considerable reinforcing effects of a disinclination of the respondents to leave their county and region as a whole because of the career prospects.

In answer to the second question, what is the contribution of labour in RIS - we suggest labour markets are critical to coordination of economic activity, through the career mobility of individuals and the networks that they take with them. Chart 2 illustrates the advantages of current location for individuals, particularly career 
possibilities, backed up by ease of finding work - as well as it being home. This study, however, gives less support to the claims of the over-riding importance of networks as a key coordinating function. Chart 3 shows that the printed advertisement, particularly in Oxfordshire was considerably more important than word of mouth as a method of finding current employment.

In sum, we suggest that more attention is paid to how labour markets operate in understanding how regional innovation systems function. The findings also have important policy implications because the case studies highlight that even in such RIS as these that are characterised by the highly-skilled, that relative shortages in supporting skills may be inhibiting factors in the further success of local and regional economies.

ACKNOWLEDGEMENTS: We thank the two referees for their constructive comments on an earlier version of this paper.

\section{REFERENCES:}

ANGEL D. P. (1991) High-technology agglomeration and the labor market: the case of Silicon Valley, Environment and Planning A, 1991, Vol. 23 pp. 1501 - 1516

ASHEIM B., and GERTLER M. (2005) 'The geography of innovation: regional innovation systems' In FAGERBERG J., MOWERY D.C., and NELSON R.R. (eds) The Oxford Handbook of Innovation Oxford: OUP

ASHEIM B., \& COENEN L. (2006) “Contextualising Regional Innovation Systems in a Globalised Learning Economy: On Knowledge Bases and Institutional Frameworks", Journal of Technology Transfer 31, pp 163-173

BACHTLER J. (2004) 'Innovation-led Regional Development: Policy Trends and Issues' Paper presented at the OECD conference on Innovation and Regional 
Development: Transition Towards a Knowledge-based Economy. Florence, Italy. November 25-26, 2004 (Unpublished)

BENNER C. (2003) 'Learning communities in a learning region: the soft infrastructure of cross-firm learning networks in Silicon Valley' Environment and Planning A 35, 1809-1830

BERRY C. R., and GLAESER E. L. (2005) 'The Divergence of Human Capital Levels Across Cities' Harvard Institute of Economic Research Discussion Paper 2091

BENNEWORTH P. (2005) Paper presented at RGS IBG Annual International Conference August 31st - September 2nd 2005, sessions on 'Universities and the Knowledge-Based Economy'

BERKCOVITZ J., and FELDMANN M. (2006) "Entrepreneurial Universities and Technology Transfer: A Conceptual Framework for Understanding Knowledge-Based Economic Development", Journal of Technology Transfer 31, pp 175-188

BROWN J. S. and DUGUID. P (2000a) The Social Life of Information Boston: Harvard University Press

BROWN J. S. and DUGUID P. (2000b). Mysteries of the region: Knowledge dynamics in Silicon Valley. The Silicon Valley edge. Stanford, CA: Stanford University Press.

CAMAGNI, R (1991) Local 'milieu', uncertainty and innovation networks: towards a new dynamic theory of economic space; in R. Camagni (ed) Innovation Networks: Spatial Perspectives, London:Belhaven Press 
CHAMPION T and COOMBES M (2005) 'Are our cities still losing human capital?

The evidence of the 'moving group' data from the 2001 Census. In: BSPS Annual

Conference 2005, University of Kent at Canterbury

http://eprints.ncl.ac.uk/file_store/nclep_461141724350.pdf (last accessed July 25

2008)

CHARTERED INSTITUTE OF PERSONNEL \& DEVELOPMENT (2001) Labour

Turnover Survey Report, London: CIPD

COHEN, W. M and LEVINTHAL, D. A (1990), 'Absorptive capacity: a new

perspective on learning and innovation', Administrative Science Quarterly, 35, 128-

152.

COOKE P. (1998) 'Regional Systems of Innovation: Introduction to the concept'

Chapter 1 in BRYCZYK H-J., COOKE P., and HEIDENREICH M. (eds) Regional Innovation Systems London:UCL Press

CURDS (2000) North East Graduate Labour Market Report Executive Summary 1999-2000, Newcastle upon Tyne, CURDS www.campus.ncl.ac.uk/unbs/ curds/Keywords2.asp?T1=Labour+Markets

DANKBAAR T. (2004) Embeddedness, Context, Proximity and Control, European Planning Studies.12, 691-701.

EDQUIST C. (2004) 'Systems of Innovation - A Critical Review of The State of the Art' in Handbook of Innovation, FAGERBERG J., MOWERY D., and NELSON R.R. Oxford:Oxford University Press

FLORIDA R, (2002) The Rise of the Creative Class New York:Basic Books

FLYNN. P. M. (1988) Facilitating technological change: The human resource challenge. Cambridge, MA: Ballinger Publishing Company. 
GARNSEY E. (1998) 'The Genesis of the High Technology Milieu: A study in

Complexity' International Journal of Urban and Regional Research 22, 3 361-377

GARNSEY, E and LAWTON SMITH H (1998) 'Proximity and Complexity in the Emergence of High Technology Industry: The Oxbridge Comparison' Geoforum 29, $4,433-450$

GREGG P. and WADSWORTH J. (1999) 'Job Tenure, 1975 - 1998' in GREGG P. and WADSWORTH J. (eds) The State of Working Britain, Manchester University Press, Manchester

GREEN, A and CANNY, A (2003) Geographical mobility: Family impacts London: Published in association with Joseph Rowntree Foundation

GREEN, A (2006) 'Labour market geographies: employment and non-employment'

Chapter 19 in S.BAGCHI-SEN and H.LAWTON-SMITH (Eds) Economic Geography: Past, Present and Future Abingdon:Routledge

HENRY N. and PINCH S. (2000) “"(The) industrial agglomeration (of Motor Sport Valley): A knowledge, space, economy approach', in BRYSON J., DANIELS P., HENRY N. and POLLARD J. (eds) Knowledge, Space, Economy, Routledge, London HOMMEN L. and DOLEREUX D. (2003) 'Is the Regional Innovation System Concept at the End of Its Life Cycle?' Paper presented for the conference 'Innovation in Europe: Dynamics, Institutions and Values' Roskilde University,Denmark, 8 th $-9^{\text {th }}$ May, 2003

HOWELLS J. (1999) 'Regional Systems of Innovation?' in ARCHIBUGI D., HOWELLS J. and MICHIE J. (Eds.) Innovation Systems in a Global Economy Cambridge University Press, Cambridge, 67-93. 
ISAKSEN A. (2005) 'Regional Clusters Building on Local and Non-Local Relations:

A European Comparison' in LAGENDIJK A. and OINAS P. (eds) Proximity,

Distance and Diversity: Issues on Economic Interaction and Local Development

Aldershot:Ashgate 129-152

KEEBLE D. (1976) Industrial location and Planning in the United Kingdom London:Methuen

KEEBLE D. (1989) 'Entrepreneurship, high-technology industry and regional development in the United Kingdom: the Case of the Cambridge Phenomenon' Environment and Planning C 7 153-172

KEEBLE D. and KELLY T. (1986) 'New firms and high technology industry in the United Kingdon: the case of computer electronics' Ch 4 inKEEBLE D. and Wever, E. (eds) New Firms and Regional Development in Europe London:Croom Helm 75-104

LAMBOOY J. (2005) "Innovation and Knowledge: Theory and Regional Policy", European Planning Studies 13(8), pp 1137 - 1152

LANCIANO-MORANDAT C. and NOHARA H. (2002) 'The scientific labour market in international perspective: a 'bridging institution' between academia and industry for the co-operation and transfer of knowledge and competences' SASE 2002 Conference Work and Labour in the Global Economy, University of Minnesota, Minneapolism Minnesota June 27- June 302002

LAWSON C. (1997) Territorial clustering and high technology innovation: from industrial districts to innovative milieux, ESRC Centre for Business Research Working Paper WP 54, University of Cambridge.

LAWTON SMITH H. (1998) 'Barriers' to technology transfer: local impediments in Oxfordshire' Environment and Planning C 16 433-448 
LAWTON SMITH H. and WATERS R. (2005) 'Employment mobility in hightechnology agglomerations: the cases of Oxfordshire and Cambridgeshire', Area, 37(2) pp.189-198

LUNDVALL B.-Å. (1988) 'Innovation as an Interactive Process: from Userproducer' Induction to the National System of Innovation. Technical Change and Economic Theory. DOSI G., FREEMAN C., SILVERBERG G., and SOETE L. (eds) London/New York, Pinter Publishers: 349-369.

MAKINEN H. (2002) 'Intra-firm and inter-firm learning in the context of start-up companies The International Journal of Entrepreneurship and Innovation 3, 1, 35-43

MALERBA F. (2002): "Sectoral Systems in Europe: Summary and conclusions”. Working Paper ESSY (http://www.cespri.it/ricerca/es_wp.htm)

MARSHALL, (1922) Principles of Economics London: Macmillan and Co

MARTIN, R and SUNLEY, P (2003) 'Deconstructing clusters: chaotic concept or policy panacea?' Journal of Economic Geography 3 5-35

MASON, G (2000) 'High-Level Technical Skills, Labour Mobility and Knowledge Transfer in Western Europe' Chapter 2 in P.Healey (ed) European Research, Technology and Development: Issues for a Competitive Future Key research findings from the ESRC Research Programme The European Context of UK Science Policy 25-34 London:SPSG

MASSEY D. (1995) Spatial Divisions of Labour: Social structures and the geography of production, MacMillan, London MYRDAL G. (1957) Economic Theory and Under-developed Regions. London: Duckworth.

OECD. (2001) Science, Technology Innovation Scoreboard Paris:OECD 
OECD. (2004) Innovation-led Policies for Regional Competitiveness Paris:OECD

ROPER S., LOVE J., COOK P., and CLIFTON N. (2006) The Scottish Innovation System: Actors Roles and Actions Report prepared by ROPER S. and LOVE J. (Aston Business School, Birmingham) and COOKE, P and CLIFTON, N (Cardiff University) http://www.scotland.gov.uk/Resource/Doc/89713/0021562.pdf SAXENIAN, A (2006) The New Argonauts: Regional Advantage in a Global Economy Boston:Harvard University Press

SCHOENBERGER E. (1999) The firm in the region and the region in the firm. In BARNES T.J and GERTLER M. (eds.), The new industrial geography: Regions, regulation and institutions. London: Routledge.

SCOTT A. (2006) 'Creative Cities: Conceptual issues and Policy Questions’ Journal of Urban Affairs 28, 1 1-17

SEGAL QUINCE. (1985) The Cambridge Phenomenon: the Growth of High Technology Industry in a University Town Cambridge:SEGAL QUINCE and Partners, Cambridge

SEGAL QUINCE WICKSTEED. (2000) The Cambridge Phenomenon Revisited Parts One and Two, SQW, Cambridge

SIMMIE J., SENNETT J., WOOD P. and HART D. (2002) "Innovation in Europe: A Tale of Networks, Knowledge and Trade in Five Cities”, Regional Studies, 36(1), pp. $47-64$

STOKER G. 2000 'Introduction' in STOKER G. (ed) The New Politics of British Government Basingstoke:Macmillan 1-10

STORPER M. (1997) The Regional World: Territorial Development in a Global Economy Guildford Press: New York 
Economy: The 20:20 Vision, Basingstoke:Palgrave Macmillan 
Box 1: Selected comments from survey respondents

Oxfordshire Physicist A

'One of the problems of becoming a specialist is that the number of posts available is automatically narrowed. In my area of expertise there are probably 200 relevant jobs world wide. About ten of them are probably in Southern England but that is almost a fluke. Having got a job that fits me this well, I am very unlikely to voluntarily change my post'.

Oxfordshire Physicist B

'Mobility is limited because when (a) one strives to be the best in one's research and (b) one is at the strongest UK university for one's research, why should one move? Only the US would represent a step up for me. Nowhere else in the UK is sufficiently attractive'.

\section{Cambridge Engineer A}

'Interesting point about Cambridge - I believe many skilled engineers live in the area despite no ties and not particularly liking the area - its the career prospects and access to starting companies that keep us here'.

\section{Cambridge Engineer B}

'Telecoms is a very incestuous market. The same faces keep appearing on projects around the world. It has a very specific skill set and a global market so skilled people can choose where they work and how much they get paid to do so'.

Table 1: Characteristics of synthetic and analytic knowledge bases

\begin{tabular}{|c|c|c|}
\hline & \multicolumn{2}{|c|}{ Knowledge Base } \\
\hline & Analytic & Synthetic \\
\hline Overview & $\begin{array}{l}\text { Industrial settings where scientific } \\
\text { knowledge is highly important and } \\
\text { knowledge creation is often based } \\
\text { on cognitive and rational processes } \\
\text { or on formal models. }\end{array}$ & $\begin{array}{l}\text { Industrial settings where innovation } \\
\text { takes place mainly through the } \\
\text { application of existing knowledge. } \\
\text { Often in response to the need to } \\
\text { solve specific problems. }\end{array}$ \\
\hline Examples & $\begin{array}{l}\text { Genetics, biotechnology, IT and } \\
\text { basic and applied research. }\end{array}$ & $\begin{array}{l}\text { Plant engineering, specialised } \\
\text { advanced industrial machinery, } \\
\text { shipbuilding. Products are often } \\
\text { one-off or small batch. }\end{array}$ \\
\hline $\begin{array}{l}\text { Knowledge inputs and } \\
\text { outputs }\end{array}$ & Codified predominates. & Tacit predominates. \\
\hline Knowledge inputs & Reviews of existing studies. & $\begin{array}{l}\text { R\&D is less important but university- } \\
\text { industry links are relevant, } \\
\text { particularly with regard to applied } \\
\text { problems. }\end{array}$ \\
\hline Knowledge generation & $\begin{array}{l}\text { Based on application of scientific } \\
\text { principles and methods. }\end{array}$ & $\begin{array}{l}\text { An inductive process of testing, } \\
\text { experimentation, computer based } \\
\text { simulation and practical work. }\end{array}$ \\
\hline Knowledge processes & Formal (eg in R\&D departments). & $\begin{array}{l}\text { Utilises know-how and craft and } \\
\text { practical skill - can be provided by } \\
\text { training. }\end{array}$ \\
\hline Outcomes & $\begin{array}{l}\text { Documented in reports, files and } \\
\text { patent descriptions. }\end{array}$ & $\begin{array}{l}\text { Modification to products and } \\
\text { processes. }\end{array}$ \\
\hline Knowledge applications & $\begin{array}{l}\text { New products or services (including } \\
\text { new firms and spin off companies - } \\
\text { sometimes based on radically new } \\
\text { inventions). }\end{array}$ & $\begin{array}{l}\text { Produces an incremental way of } \\
\text { innovation, dominated by the } \\
\text { modification of existing products and } \\
\text { processes - spin offs are not } \\
\text { common. }\end{array}$ \\
\hline
\end{tabular}

Source: Asheim and Coenen, 2006 
Table 2: Educational Attainment in Oxfordshire and Cambridgeshire

\begin{tabular}{|c|c|c|c|c|c|c|c|c|}
\hline & \multicolumn{4}{|c|}{ Percentage } & \multicolumn{4}{|c|}{ Total } \\
\hline & 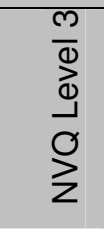 & 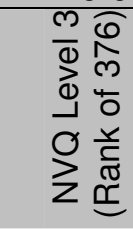 & $\begin{array}{l}+ \\
\stackrel{+}{\Phi} \\
\stackrel{D}{J} \\
\stackrel{0}{O}\end{array}$ & 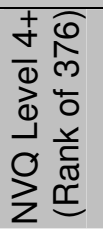 & 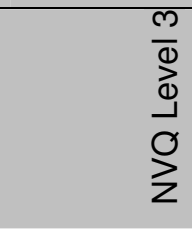 & 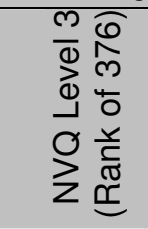 & $\begin{array}{l}\frac{+}{d} \\
\frac{1}{0} \\
\frac{1}{0} \\
0 \\
z\end{array}$ & 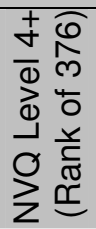 \\
\hline East of England & 7,9 & $\begin{array}{r}4 \text { (of 9) } \\
4 \text { (of }\end{array}$ & 18,1 & 4 & 308.581 & $\begin{array}{r}4 \text { (of } 9 \text { ) } \\
21 \text { (of }\end{array}$ & 704.743 & 4 \\
\hline Cambridgeshire & 9,5 & 42) & 25,2 & 6 & 38.458 & 42) & 102.528 & 17 \\
\hline $\begin{array}{l}\text { Cambridge } \\
\text { East }\end{array}$ & 18,0 & 2 & 41,2 & 8 & 15.324 & 40 & 35.145 & 45 \\
\hline Cambridgeshire & 7,2 & 210 & 20,2 & 136 & 3.842 & 313 & 10.712 & 278 \\
\hline Fenland & 5,0 & 370 & 9,5 & 370 & 3.014 & 339 & 5.681 & 358 \\
\hline $\begin{array}{l}\text { Huntingdonshire } \\
\text { South }\end{array}$ & 8,0 & 142 & 20,0 & 140 & 9.096 & 111 & 22.726 & 98 \\
\hline Cambridgeshire & 7,6 & 175 & 29,8 & 29 & 7.182 & 152 & 28.264 & 67 \\
\hline South East & 9,2 & $\begin{array}{r}2 \text { (of 9) } \\
1 \text { (of }\end{array}$ & 21,8 & 2 & 530.682 & $\begin{array}{r}1 \text { (of 9) } \\
15 \text { (of }\end{array}$ & 1.253 .917 & 2 \\
\hline Oxfordshire & 10,8 & 42) & 27,7 & 2 & 48.177 & 42) & 123.323 & 14 \\
\hline Cherwell & 7,7 & 169 & 20,0 & 139 & 7.329 & 147 & 19.169 & 128 \\
\hline Oxford & 19,0 & 1 & 36,9 & 12 & 19.763 & 21 & 38.301 & 38 \\
\hline South Oxfordshire & 8,9 & 94 & 28,3 & 39 & 8.222 & 129 & 26.261 & 76 \\
\hline Vale of White Horse & 8,7 & 106 & 28,2 & 41 & 7.234 & 151 & 23.576 & 87 \\
\hline West Oxfordshire & 8,2 & 130 & 23,3 & 79 & 5.629 & 213 & 16.016 & 169 \\
\hline England & 8,3 & - & 19,9 & - & 2.962.282 & - & 7.072 .052 & - \\
\hline England and Wales & 8,3 & - & 19,8 & - & 3.110 .135 & - & 7.432 .962 & - \\
\hline
\end{tabular}

Source: Census, ONS, 2001 
Table 3: Managerial, Professional and Technical Workers in Oxfordshire and Cambridgeshire (\% of respondents)

\begin{tabular}{|c|c|c|c|c|c|c|c|c|}
\hline & \multicolumn{2}{|c|}{ soc1 } & \multicolumn{2}{|c|}{ SOC2 } & \multicolumn{2}{|c|}{ soc3 } & \multicolumn{2}{|c|}{ SOCs 1-3 } \\
\hline & $\%$ & Rank & $\%$ & Rank & $\%$ & Rank & $\%$ & Rank \\
\hline East of England & 16,3 & 3 (of 9) & 10,8 & 3 (of 9) & 13,6 & 4 (of 9) & 40,6 & $3($ of 9$)$ \\
\hline Cambridgeshire & 16,4 & 15 (of 42$)$ & 14,7 & 3 (of 42 ) & 13,8 & 14 (of 42 ) & 44,9 & 7 (of 42 ) \\
\hline Cambridge & 13,2 & 275 & 28,0 & 2 & 14,2 & 116 & 55,3 & 15 \\
\hline East Cambridgeshire & 17,3 & 93 & 10,9 & 156 & 12,7 & 223 & 40,9 & 140 \\
\hline Fenland & 12,8 & 285 & 6,7 & 355 & 10,8 & 349 & 30,3 & 348 \\
\hline Huntingdonshire & 18,1 & 70 & 10,5 & 169 & 14,7 & 94 & 43,2 & 113 \\
\hline South Cambridgeshire & 18,2 & 68 & 16,6 & 21 & 14,9 & 87 & 49,7 & 42 \\
\hline South East & 17,4 & 2 (of 9 ) & 12,1 & 2 (of 9) & 14,6 & 2 (of 9 ) & 44,2 & 2 (of 9$)$ \\
\hline Oxfordshire & 17,4 & 7 (of 42$)$ & 15,0 & 2 (of 42 ) & 15,2 & 6 (of 42) & 47,5 & 4 (of 42) \\
\hline Cherwell & 17,0 & 103 & 10,3 & 182 & 14,4 & 101 & 41,7 & 127 \\
\hline Oxford & 12,8 & 284 & 23,4 & 3 & 15,8 & 50 & 52,0 & 31 \\
\hline South Oxfordshire & 20,8 & 24 & 14,3 & 49 & 15,4 & 63 & 50,6 & 35 \\
\hline Vale of White Horse & 18,6 & 64 & 15,6 & 31 & 14,3 & 107 & 48,5 & 48 \\
\hline West Oxfordshire & 17,4 & 87 & 11,4 & 137 & 16,0 & 43 & 44,8 & 86 \\
\hline England & 15,3 & - & 11,2 & - & 13,8 & - & 40,3 & \\
\hline England and Wales & 15,1 & - & 11,2 & - & 13,8 & - & 40,1 & - \\
\hline
\end{tabular}

Source: Census, ONS, 2001

Table 4: Comparative mean job tenure

\begin{tabular}{|lll|}
\hline Territory & $\begin{array}{l}\text { Average Job Tenure } \\
\text { (Years) }\end{array}$ \\
UK overall (2001) & & 6,7 \\
UK SOC 2 & 4,6 \\
UK IT \& high technology & 5,1 \\
Motorsport Valley (UK, 2000) & 3,7 \\
\hline
\end{tabular}

Source: CBI, 2002, CIPD, 2001, HENRY and PINCH, 2000

Table 5: Responses to the survey of the highly skilled

\begin{tabular}{|lrrrr|}
\hline & IEE & IOP & RSC & Total \\
Oxfordshire & 62 & 282 & 83 & 427 \\
Cambridgeshire & 105 & 182 & 115 & 402 \\
Total & 167 & 464 & 198 & 829 \\
\hline
\end{tabular}

Source: Authors' survey 
Table 6: Overview of the careers of the highly skilled

\begin{tabular}{|lrrr|}
\hline & \multicolumn{1}{l}{ IEE } & \multicolumn{1}{l|}{ IOP } & \multicolumn{1}{c|}{ RSC } \\
\hline Cambridgeshire & & & \\
All in Cambridgeshire & - & 19,2 & 19,0 \\
In \& Out & 12,1 & 11,6 & 9,5 \\
One Way & 62,6 & 46,6 & 52,4 \\
First Job & 25,2 & 22,6 & 19,0 \\
& & & \\
Oxfordshire & & & \\
All in Oxfordshire & - & 15,8 & 23,3 \\
In \& Out & 8,1 & 8,5 & 6,8 \\
One Way & 75,8 & 50,6 & 56,2 \\
First Job & 16,1 & 25,1 & 13,7 \\
\hline
\end{tabular}

Source: Authors' survey

Table 7: Migration in Oxfordshire and Cambridgeshire

\begin{tabular}{|c|c|c|c|c|c|c|}
\hline & \multicolumn{3}{|c|}{ Lived at same address one year ago } & \multicolumn{3}{|c|}{ Lived elsewhere - outside the UK } \\
\hline & No. & $\%$ & Rank (of 376) & No. & $\%$ & Rank (of 376 ) \\
\hline East & 4.764.140 & 88,4 & 5 (of 10$)$ & 36.577 & 0,7 & 3 (of 10) \\
\hline Cambridgeshire & 472.471 & 85,5 & 33 (of 34) & 7.894 & 1,4 & 2 (of 34) \\
\hline $\begin{array}{l}\text { Cambridge } \\
\text { East }\end{array}$ & 81.810 & 75,1 & 375 & 4.423 & 4,1 & 4 \\
\hline Cambridgeshire & 64.373 & 87,9 & 251 & 705 & 1,0 & 74 \\
\hline Fenland & 73.683 & 88,2 & 233 & 186 & 0,2 & 321 \\
\hline $\begin{array}{l}\text { Huntingdonshire } \\
\text { South }\end{array}$ & 137.985 & 87,9 & 252 & 1.287 & 0,8 & 87 \\
\hline Cambridgeshire & 114.620 & 88,1 & 239 & 1.293 & 1,0 & 68 \\
\hline South East & 6.984 .762 & 87,3 & 8 (of 10) & 71.285 & 0,9 & 8 (of 10) \\
\hline Oxfordshire & 512.874 & 84,7 & 34 (of 34 ) & 9.675 & 1,6 & 1 (of 34) \\
\hline Cherwell & 114.972 & 87,2 & 284 & 977 & 0,7 & 99 \\
\hline Oxford & 100.144 & 74,6 & 376 & 5.158 & 3,8 & 6 \\
\hline South Oxfordshire & 112.451 & 87,7 & 268 & 1.130 & 0,9 & 79 \\
\hline Vale of White Horse & 100.842 & 87,2 & 288 & 1.714 & 1,5 & 29 \\
\hline West Oxfordshire & 84.465 & 88,3 & 220 & 696 & 0,7 & 102 \\
\hline $\begin{array}{l}\text { England } \\
\text { England and }\end{array}$ & 43.124 .923 & 87,8 & - & 360.511 & 0,7 & - \\
\hline Wales & 45.703.875 & 87,8 & - & 370.430 & 0,7 & - \\
\hline
\end{tabular}

Source: Census, ONS, 2001 


\section{Chart 1: Where Oxfordshire and Cambridgeshire scientists will look for their next position}

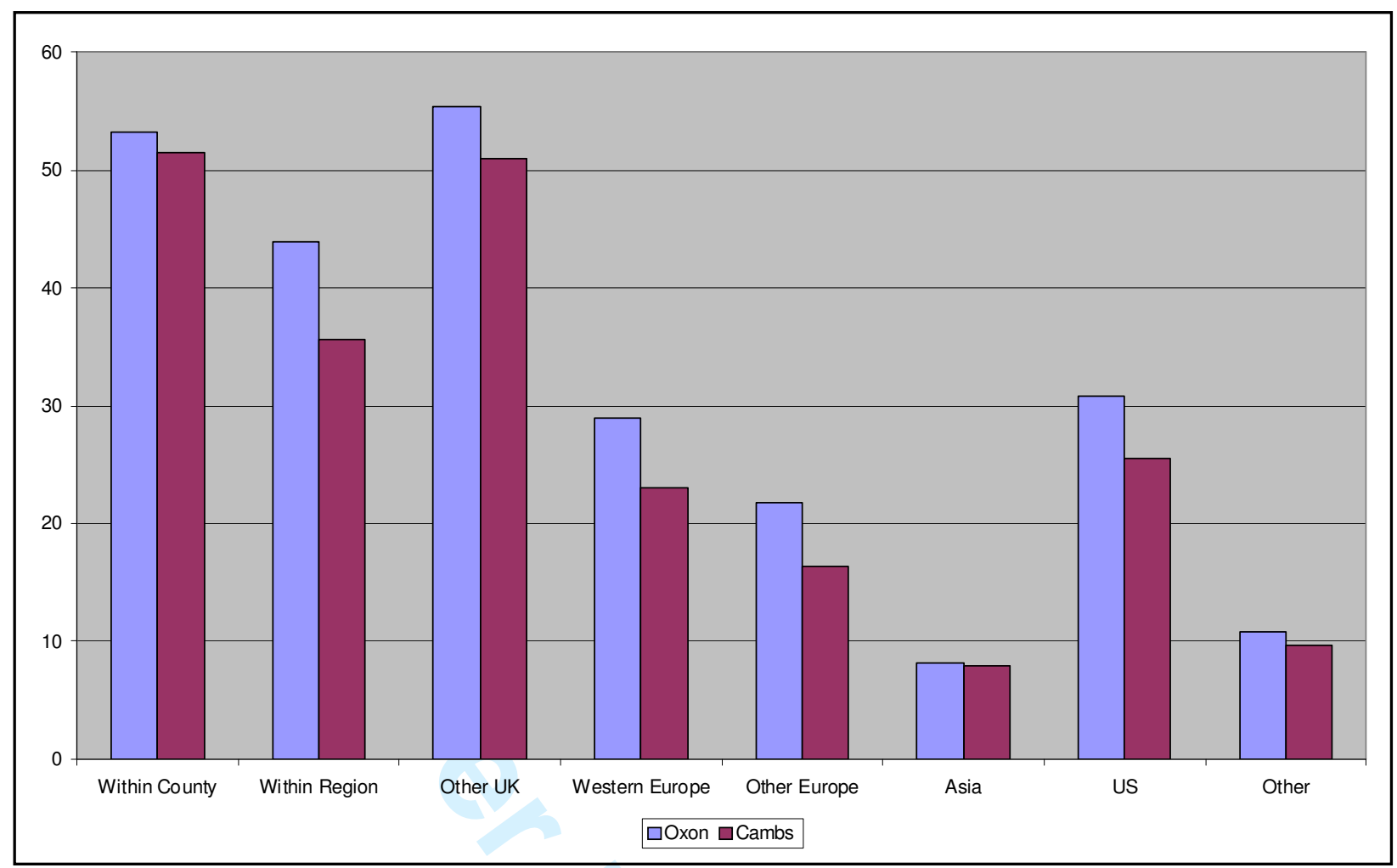




\section{Chart 3: Method of finding current employment}

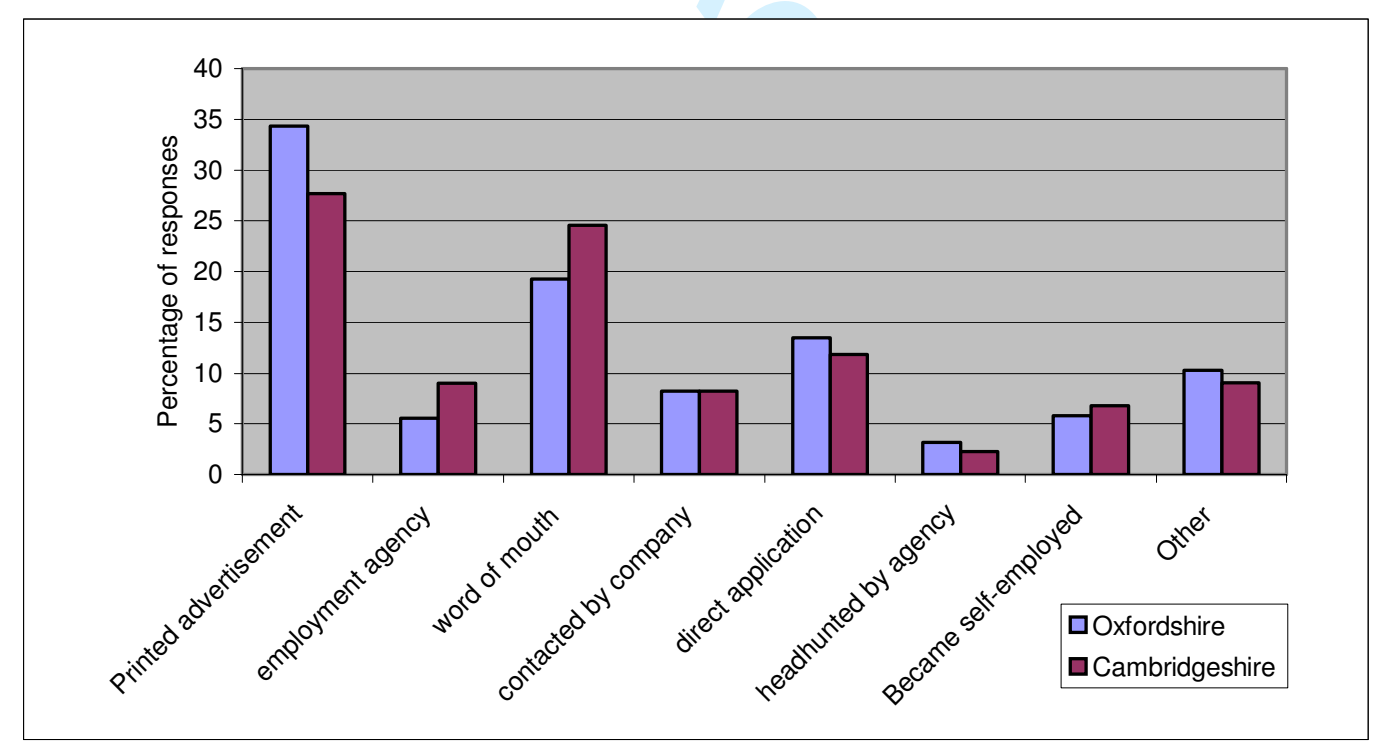


Chart 4: Method of finding current employment by number of jobs (per cent)

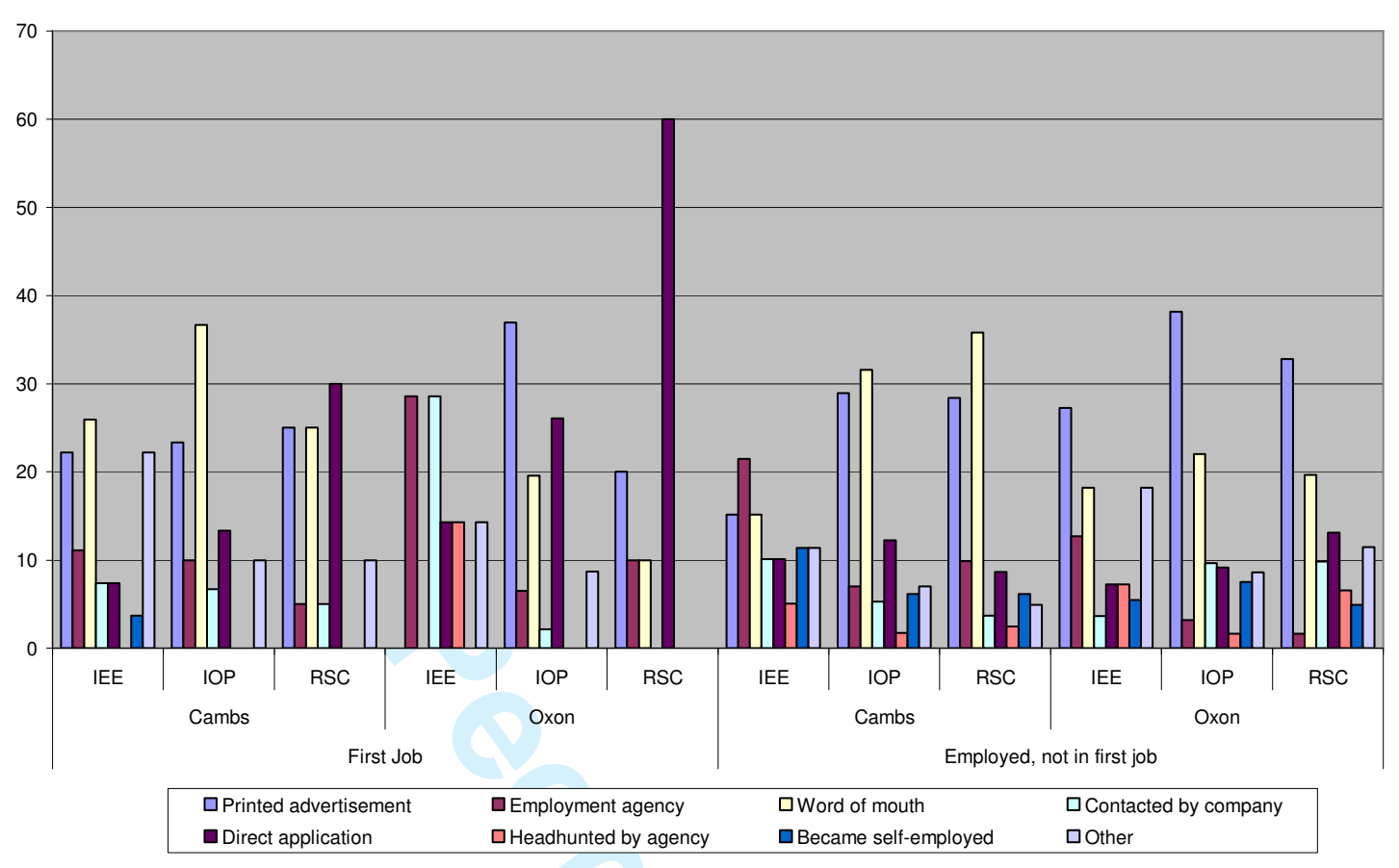

